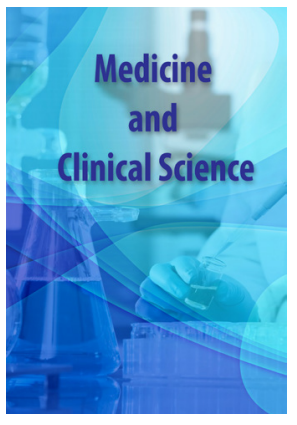

Correspondence

Sun Yeob Choi

Ewha Womans Universtiy Mokdong Hospital 1071 Anyangchon-ro, Yangcheon-gu, Seoul 07995, Korea

E-mail:ck9309@naver.com

Tel: +82-2-2650-5360

Fax: $+82-2-2650-5058$

\footnotetext{
- Received Date: 03 Jan 2020;

- Accepted Date: 28 Jan 2020;

- Publication Date: 14 Feb 2020.
}

\section{Copyright}

(c) 2020 Science Excel. This is an openaccess article distributed under the terms of the Creative Commons Attribution 4.0 International license.

\title{
Korean nurses' attitude towards withdrawing life sustaining treatment: A review of literature
}

\author{
Sun Yeob Choi \\ Master's Student, College of Nursing, Ewha Womans University, Seoul, Korea \\ Nurse, Ewha Womans Universtiy Mokdong Hospital, Seoul, Korea
}

\section{Introduction}

The aim of this study was to review nurses' attitude toward withdrawing life sustaining treatment in Korea. Life sustaining treatment is medical treatment which prolong the end of life stage but not curing patient's disease. Cardiopulmonary resuscitation, hemodialysis, mechanical ventilator, and other medical treatment prescribed by Presidential Decree were included in life sustaining treatment [1]. Life sustaining treatment made life extension possible, but this caused the patient to suffer and family to experience financial burdens [2]. Withdrawing life sustaining treatment means that patients who are deemed to be in dying process do not perform the life-long treatment for the purpose of extending the dying period without treatment effects [3].

In 2009, Korea Supreme Court approved the removal of a life support device for a 75-year-old patient in a coma on demand of her families [4]. This incident formed a public opinion that the life sustaining treatment could hurt patients' dignity [5]. So, Life-sustaining treatment decisions Act was enacted in 2016 and was in force in 2018. But withdrawing life sustaining was confused with DNR [6], and nurses face a dilemma between extending lives and withdrawing life sustaining treatment [7]. Nurses give care for $24 \mathrm{hrs}$ nearby patients and spend most of time with patients at the end of life [8], so they can understand patients intention and wishes. Patients and their family make withdrawing life sustaining decision based on medical staff's attitude and opinion $[9,10]$. Attitudes toward withdrawing life sustaining treatment are subjective and vary depending on personal characteristics and values $[9,11]$. Therefore it is necessary to understand nurses' attitude toward life sustaining treatment.

\section{Method of Review}

TA research was reviewed utilizing the six electronic databases(Riss, NDSL, PubMed, CINAHL and Web of science). The key words are nurses, Korean, attitude, end-of-life care, withdrawal, withdrawing, withdrawing life sustaining treatment, end-of-life decision. Peer-reviewed research article, written in Korean or English, reporting on nurses and withdrawing life sustaining treatment was included. Commentaries, narratives, books, conference abstracts, review letters, dissertations were excluded. The literature review initially identified 235 studies, 32 are duplications, 23 are conference abstracts, 100 are not about Korean nurses, and 71 are not about attitude. Finally total 9 studies met the selection criteria.

\section{Findings}

Characteristics of the studies

The reviews are based on 9 studies, published between 2003 and 2018. It included 1549 nurses in Korea. 6 were multicenter studies, 2 were single center study and 1 for home care nurses. The 5 studies' nurses worked in general hospitals, 3 studies' participants in university hospitals and a study are for home care nurse. 4 of 9 studies had nurses working at intensive care unit (ICU).

\section{Measurement}

All studies use same tool to measure attitude toward withdrawing life sustaining life sustaining treatment which was developed by Byun, et al. in 2003 [12]. The tool consists of 15 questions expressing positive attitude and 4 questions indicating negative attitude toward withdrawing life sustaining treatment. It was measured on a 5 Likert scale from 1 'not at all' to 5 'very well'. The 4 questions expressing the negative attitude were reversed. The score range from 0-5 and the higher score means more favorable in withdrawing life sustaining treatment.

Attitudes toward withdrawing life sustaining treatment

Most nurses in studies show positive attitude toward withdrawing life sustaining treatments. The average of study, where the measurement tool of attitude toward withdrawing life sustaing treatment was first presents, was 3.28 [12]. ICU nurses attitude toward withdrawing life sustaining treatment was 3.23 [13] and 3.33 out of 5 [9]. The home care nurses' score was 3.28 [5] and tertiary general hospital nurses' score was 3.5 out of 5 [14]. Kim \& Kim study's nurses who worked in six general hospitals agreed on withdrawing life sustaining treatment and the score was 3.2 out of 5 [15]. The attitude toward life sustaining treatment with experience in caring DNR patient was 2.6 and that of those with no experience in DNR was 2.69 [16].

\section{Characteristics affecting attitude toward} life sustaining treatment

Gender: There was statistically significant differences in attitude toward withdrawing life sustaining treatment by gender. Men has more negative attitude toward life sustaining treatment than women [11]. It can be explained by differential socialization of men and women [17]. Women have higher level of death anxiety [17] so women perhaps want to prolong lives. However, in other studies $[9,12]$ gender was not a significant factor that affected attitude toward withdrawing life sustaining treatment. A study conducted in Iran showed that men were more positive attitude toward life -support and this result 
can be interpreted by male-dominant cultures [18].

Experience: Attitude toward withdrawing life sustaining treatment differed by nursing experience. The higher the working experience, the more positive attitude toward withdrawing life sustaining treatment $[9,15]$. ICU nurses who have 37-38 months of experience have more positive attitude than nurses who have 12 months of work experience [9]. It can be inferred that the more nursing experience one has, the more positive attitude in death and caring for dying patients [19-21]. Exposure to death will allow nurses to better understand their emotions [17] and further improve and develop their coping skills to care for dying patients [22]. Also, it can be interpreted in a similar context that nurses establish their perception of withdrawing life sustaining treatment thorough their experience in provide life sustaining care [7]. For these reasons, it is interpreted that nurses with more career have more positive about withdrawing life sustaining treatment.

Working unit: Attitude toward withdrawing life sustaining treatment differed by working unit. Participants who work in hospice care show more positive attitude toward withdrawing life sustaining treatment than those who work in Emergency room and operating room [14]. This results can be interpreted in that nurses in hospice ward experience more death and dying patients. In addition, nurses in ICU, where life sustaining treatment is frequently performed, are well aware of withdrawing life sustaining treatment. In can be inferred that ICU nurses have been exposed to patients suffering and harming dignity through life sustaining treatment in the working place [23,24].

Family death experience: Experiencing the death of another person changes one's attitude of end-of-life decision [25]. For this reason, it can be inferred that nurses who experience family death have more positive attitude toward withdrawing life sustaining treatment [15].

\section{Variables related to attitude toward life sustaining treatment}

Attitude toward withdrawing life sustaining treatment has positive correlation with role perception [9]. Role perception means awareness of the active role of nurses during the withdrawing life sustaining treatment. This can be interpreted that nurses who are more negative about life sustaining treatment to be more aware of their role as a patient counselor and supporter of life-time care [9]. Nurses with positive attitude toward withdrawing life sustaining treatment had higher awareness of patient determination rights [5]. There is positive correlation between attitude toward withdrawing life sustaining treatment and good death perception [14]. It can be inferred from the fact that the purpose of withdrawing life sustaining treatment is to guarantee patients' right to die with dignity.

There was positive correlation toward withdrawing life sustaining treatment and attitude toward euthanasia [15]. This seems to be due to the similarities in the concept that both determine the discontinuation retention of treatment in an irreversible state [15]. There was negative correlation between attitude toward withdrawing life sustaining treatment and knowledge of withdrawing life sustaining treatment [2]. This correlation between knowledge and attitude can be explained in that knowledge explains attitude and that knowledge must precede changes in attitude $[26,27]$. There was only one study that conducted regression analysis. Attitude toward withdrawing life sustaining treatment was affected by working at hospice ward, attitude about tissue donation and tissue transplantation, and awareness of hospice palliative care. Attitude toward withdrawing life sustaining treatment was explained by $32.5 \%$ by variances [14].

\section{Conclusion}

Most nurses in studies show positive attitude toward withdrawing life sustaining treatments. Nurses with established attitude toward life sustaining treatment can play the role of advocates and educators of patients in end of life decision $[28,29]$. Also it is necessary not only to protect the patients' right of life but also to protect nurses and to free them from ethical dilemmas [30]. However, due to lack of system, education, and knowledge about life sustaining treatment nurses have difficulty recognizing their roles and attitudes in end of life decisionmaking [31]. And nurses are experiencing confusion and emotional exhaustion in withdrawing life sustaining treatment [13]. So, education and intervention was needed for nurses to identify and establish their attitudes toward withdrawing life sustaining treatment.

Since, the research on attitude toward life sustaining treatment is still in its early stage, I recommend that follow research is necessary. Also, in Korea Life-sustaining treatment decisions Act does not specify the role of nurses in withdrawing life sustaining treatment. However, patients and families expect the participant of nurses in end of life decisionmaking [32], and both doctors and patients' families recognize the role of nurses in withdrawing life sustaining treatment positively [33]. So, it is necessary to establish the role of nurses in end of life decision making process. Finally, since the tool currently in use was developed in 2003, it is recommended measurement be developed in accordance with the provisions of the current law in force.

\section{References}

1. Ministry of Health and Welfare. Guidance on the Annual Health Care Decision System. Ministry of Health and Welfare: Seoul. 2019

2. Kim MH, Kang EH, Kim MY. Family decision-making to withdraw lifesustaining treatment for terminally-ill patients in an unconscious state. Korean J Hosp Palliat Care. 2012;15(3):147-154.

3. Jeon JH. Difference between Medical Students and Nursing Students about Awareness and Attitude toward Withdrawal of Life-Sustaining Medical Treatment. Journal of the Korea Convergence Society. 2019; 10(8): 335-344.

4. Heo DS. Life-sustaining medical treatment for terminal patients in Korea. J Korean Med Sci. 2013;28(1):1-3.

5. Kwon YO, Ahn SH. The attitude and perception on withdrawal of futile life sustaining treatment and patient self determination right among home care nurses. J Korean Bioethics Assoc 2013;14(2):53-66.

6. Jang NS, Park HS, Kim MR, et al. Knowledge, Confidence, and Learning Needs Regarding Advance Directives among Hospital Nurses. J Korean Crit Care Nurs. 2018;11(1):35-45.

7. Lee SJ , Kim HY. Experience of Life-sustaining Treatment in Patient Care among Intensive Care Unit Nurses: Phenomenological Approach. J Korean Acad Fundam Nurs. 2016;23(2):172-183.

8. Dickinson GE, Clark D, Sque M. Palliative care and end of lifeissues in UK preregistration, undergraduate nursing programmes. Nurs Educ Today. 2008;28(2):163-170.

9. Lee SJ , Kim HY. Attitude, role perception and nursing stress on life sustaining treatment among intensive care unit nurses. Korean J Adult Nurs. 2017;29(2):131-142.

10. Monteiro F. Family reliance on physicians' decisions in life-sustaining treatments in acute-on-chronic respiratory diseases in a respiratory ICU: A single-center study. Respir Care. 2014;59(3):411-419.

11. Yeun EJ, Lee MY, Song MS. Attitudes toward life sustaining treatment among Korean adults: An application of Q-methodology. Journal of KSSS 2011;22:129-145.

12. Byun EK, Choi HR, Choi $A L$, et al. An investigative research on the attitudes of intensive care unit nurses and families on terminating life support. J Korean Clin Nurs Res. 2013;9(1):112-124.

13. Um JK, Suh GH, Park SA. Life-sustaining treatment attitude, stress and advanced directives awareness in ICU nurses. Journal of the Korean Bioethics Association.2018;19(1):37-50.

14. Je NJ, Hwa JS. Factors influencing withdrawal of life-sustaining treatment in teritary general hospital workers knowledge and attitude of orgarn donation and transplantation, awarness of death, knowledge and perception of hospice pallitative care. Korean J Hosp Palliat Care. 2018;21(3):92-103.

15. Kim SN, Kim HJ. Recognition of good death, attitude towards the withdrawal of life-sustaining treatment, and attitude towards euthanasia in nurses. Korean J Hosp Palliat Care. 2016;19(2):136-144.

16. Kim SJ, Kim HS, Chae Y, et al. The effect of Nurses' experiences with DNR orders on their knowledge and attitudes concerning with the withdrawal of life-sustaining treatment. Korean J Med Ethics. 2012;15(3):355-369.

17. Khader KA, Jarrah SS, Alasad J. Influence of nurses characteristics and 
education on their attitudes towards death and dying: A review of literature. Int J Midwifery Nurs Pract. 2010;2(1):1-9.

18. Razban F, Iranmanesh S, Aliabadi HE, et al. Critical care nurses' attitude towards life-sustaining treatments in South East Iran. World J Emerg Med. 2016; 7(1):59.

19. Lange $M$, Thom B, Kline N. Assessing nurses' attitudes toward death and caring for dying patients in a comprehensive cancer center. Oncol Nurs Forum. 2008;35(6):955-959.

20. Wilkes LM, Beale B. Palliative care at home: stress for nurses in urban and rural New South Wales, Australia. Int J Nurs Pract.2001; 7(5):306313.

21. Miyashita $M$, Nakai $Y$, Sasahara $T$, et al. Nursing autonomy plays an important role in nurses' attitudes toward caring for dying patients. Am J Hosp Palliat Care. 2007;24(3):202-210.

22. Weigel C, Parker G, Fanning L, et al. Apprehension among hospital nurses providing end-of-life care. J Hosp Palliat Nurs. 2007;9(2):86-91.

23. Kang JH, Lee YM, Lee HJ. Effect of the awareness of a good death and perceptions of life-sustaining treatment decisions on attitudes of intensive care nurses toward terminal care. J Korean Crit Care Nurs. 2019;12(2):39-49.

24. Kelley AS, McGarry K, Fahle S, et al. Out-of-pocket spending in the last five years of life. J Gen Intern Med. 2013;28(2):304-309.

25. Barrere CC, Durkin A, LaCoursiere S. The influence of end-of-life education on attitudes of nursing students. Int J Nurs Educ Scholarsh. 2008;5(1):1-18.

26. Ayed A, Sayej S, Harazneh L, et al. The Nurses' Knowledge and Attitudes towards the Palliative Care. Journal of Education and Practice. 2015;6(4):91-99.

27. Schrader PG, Lawless KA. The knowledge, attitudes, \& behaviors approach how to evaluated performance and learning in complex environments. Performance Improvement. 2004;43(9):8-15.

28. Jang YM, Ahn EK. The effects of moral sensitivity, biomedical ethics awareness on attitudes toward withdrawal of life-sustaining treatment of nursing students. Journal of industrial convergence. 2019;17(2):5361.

29. Comrie RW. An analysis of undergraduate and graduate student nurses moral sensitivity. Nurs Ethics. 2012;19(1):116-127.

30. Kim JS. Development and effect of advance directives education program for nursing students. Journal of the Korean Data Analysis Society. 2019;21(4):2131-2149.

31. Nankundwa E, Brysiewicz P. Lived experiences of Rwandan ICU nurses caring for patients with a do-not-resuscitate order. S Afr Med J. 2017;33(1):19-22

32. Beckstrand RL, Lamoreaux N, Luthy $\mathrm{KE}$, et al. Critical care nurses' perceptions of end-of-life care obstacles: Comparative 17-year data. Dimens Crit Care Nurs. 2017;36(2):94-105.

33. Lee HK, Kang HS. Attitudes and awareness towards the withdrawal of life-sustaining treatment among nurses, physicians, and families of intensive care unit patient. J Korean Clin Nurs Res. 2010; 16(3):85-98.

34. Kim JS, Moon SM, Nam KA. Nurses and physicians' attitude toward withdrawal of life-sustaining treatment and knowledge of the guideline of withdrawal of life-sustaining treatment. J East-West Nurs

\begin{tabular}{|c|c|c|c|c|c|c|}
\hline $\begin{array}{l}\text { First Author } \\
\text { (Year of } \\
\text { publication) }\end{array}$ & Study Design & Setting & $\begin{array}{l}\text { Data } \\
\text { Collection } \\
\text { Method }\end{array}$ & Sample & $\begin{array}{l}\text { Attitude toward WLST } \\
\text { (a five-point scale) }\end{array}$ & Key Findings \\
\hline $\begin{array}{l}\text { Byun et al } \\
(2003)[12]\end{array}$ & $\begin{array}{l}\text { Cross-sectional } \\
\text { study }\end{array}$ & $\begin{array}{l}\text { ICU from } 2 \\
\text { university } \\
\text { hospitals }\end{array}$ & $\begin{array}{l}\text { Self-reported } \\
\text { questionnaire } \\
\text { developed by } \\
\text { Byun (2003) }\end{array}$ & $\begin{array}{l}101 \text { ICU nurses } \\
88 \text { families of } \\
\text { ICU }\end{array}$ & $\begin{array}{l}\text { The mean score of nurses' } \\
\text { was } 3.28 \\
\text { The mean score of } \\
\text { families' was } 3.26\end{array}$ & $\begin{array}{l}\text { Both ICU nurses and } \\
\text { families had positive attitude } \\
\text { toward WLST } \\
\text { ICU nurses and families } \\
\text { recognized nurses' important } \\
\text { role in end of life decision. }\end{array}$ \\
\hline $\begin{array}{l}\text { Lee \& Kang } \\
\text { (2010) [33] }\end{array}$ & $\begin{array}{l}\text { Cross-sectional } \\
\text { study }\end{array}$ & $\begin{array}{l}8 \text { general } \\
\text { hospitals }\end{array}$ & $\begin{array}{l}\text { Self-reported } \\
\text { questionnaire } \\
\text { developed by } \\
\text { Byun (2003) }\end{array}$ & $\begin{array}{l}80 \text { ICU nurses } \\
80 \text { physicians } \\
80 \text { families of } \\
\text { ICU }\end{array}$ & $\begin{array}{l}\text { The mean score of } \\
\text { nurses' was } 3.36 \\
\text { The mean score of } \\
\text { physicians' was } 3.30 \\
\text { The mean score of } \\
\text { families' was } 3.63\end{array}$ & $\begin{array}{l}\text { Both nurses, physicians and } \\
\text { families had positive attitude } \\
\text { toward WLST } \\
\text { Both nurses, physicians, } \\
\text { and families recognized the } \\
\text { need of guidelines in making } \\
\text { decision of WLST } \\
\text { Physicals and families } \\
\text { recognized positively of } \\
\text { nurses' role in decision- } \\
\text { making of WLST }\end{array}$ \\
\hline $\begin{array}{l}\text { Kim et al } \\
(2012)[16]\end{array}$ & $\begin{array}{l}\text { Cross-sectional } \\
\text { study }\end{array}$ & $\begin{array}{l}\text { a general } \\
\text { hospital }\end{array}$ & $\begin{array}{l}\text { Self-reported } \\
\text { questionnaire } \\
\text { developed by } \\
\text { Byun (2003) }\end{array}$ & $\begin{array}{l}245 \text { nurses } \\
86 \text { nurses with } \\
\text { DNR care } \\
\text { experience } \\
159 \text { nurses } \\
\text { without DNR } \\
\text { care experience }\end{array}$ & $\begin{array}{l}\text { The mean score was } 2.6 \\
\text { with experience in caring } \\
\text { DNR patient } \\
\text { The mean score was } 2.69 \\
\text { with no experience }\end{array}$ & $\begin{array}{l}\text { There was no significant } \\
\text { difference between two } \\
\text { groups of nurses. } \\
\text { There was negative } \\
\text { correlation between } \\
\text { attitude toward WLST and } \\
\text { knowledge of WLST }\end{array}$ \\
\hline
\end{tabular}




\begin{tabular}{|c|c|c|c|c|c|c|}
\hline $\begin{array}{l}\text { Kwon \& Ahn } \\
\text { (2013) [5] }\end{array}$ & $\begin{array}{l}\text { Cross-sectional } \\
\text { study }\end{array}$ & $\begin{array}{l}\text { home care } \\
\text { nurses }\end{array}$ & $\begin{array}{l}\text { Self-reported } \\
\text { questionnaire } \\
\text { developed by } \\
\text { Byun (2003) }\end{array}$ & $\begin{array}{l}136 \text { home care } \\
\text { nurses }\end{array}$ & The mean score was 3.28 & $\begin{array}{l}\text { There was positive } \\
\text { correlation between } \\
\text { attitude toward WLST and } \\
\text { perception of patients self- } \\
\text { determination right. } \\
\text { There was no correlation } \\
\text { between attitude toward } \\
\text { WLST and the role } \\
\text { perception of WLST. }\end{array}$ \\
\hline $\begin{array}{l}\text { Kim \& Kim } \\
(2016)[15]\end{array}$ & $\begin{array}{l}\text { Cross-sectional } \\
\text { study }\end{array}$ & $\begin{array}{l}6 \text { general } \\
\text { hospitals } \\
\text { with } 500 \text { or } \\
\text { more beds }\end{array}$ & $\begin{array}{l}\text { Self-reported } \\
\text { questionnaire } \\
\text { developed by } \\
\text { Byun (2003) }\end{array}$ & 218 nurses & The mean score was 3.2 & $\begin{array}{l}\text { Attitude toward WLST } \\
\text { was Significantly different } \\
\text { by length of career and } \\
\text { experience of family death } \\
\text { There was negative } \\
\text { correlation between attitude } \\
\text { toward WLST and good } \\
\text { death perception } \\
\text { There was positive } \\
\text { correlation between attitude } \\
\text { toward WLST and attitude } \\
\text { toward euthanasia }\end{array}$ \\
\hline $\begin{array}{l}\text { Kim, Moon, } \\
\& \text { Nam (2017) } \\
{[34]}\end{array}$ & $\begin{array}{l}\text { Cross-sectional } \\
\text { study }\end{array}$ & $\begin{array}{l}3 \text { university } \\
\text { hospitals }\end{array}$ & $\begin{array}{l}\text { Self-reported } \\
\text { questionnaire } \\
\text { developed by } \\
\text { Byun (2003) }\end{array}$ & $\begin{array}{l}345 \text { nurses, } 88 \\
\text { physicians }\end{array}$ & $\begin{array}{l}\text { The mean score of nurses' } \\
\text { was } 3.27 \\
\text { The mean score of } \\
\text { physicians' was } 3.26\end{array}$ & $\begin{array}{l}\text { Both physicians and nurses } \\
\text { had positive attitude toward } \\
\text { WLST and there was no sig- } \\
\text { nificant difference between } \\
\text { nurses and physicians. } \\
\text { Nurses' knowledge of } \\
\text { guideline of life sustaining } \\
\text { treatment was higher than } \\
\text { physicians. }\end{array}$ \\
\hline $\begin{array}{l}\text { Lee \& Kim } \\
\text { (2017) [9] }\end{array}$ & $\begin{array}{l}\text { Cross-sectional } \\
\text { study }\end{array}$ & $\begin{array}{l}\text { ICU from } \\
11 \text { general } \\
\text { hospitals }\end{array}$ & $\begin{array}{l}\text { Self-reported } \\
\text { questionnaire } \\
\text { developed by } \\
\text { Byun (2003) }\end{array}$ & 202 ICU nurses & The mean score was 3.33 & $\begin{array}{l}\text { Attitude toward WLST } \\
\text { was Significantly different } \\
\text { by working experience } \\
\text { as a nurse and working } \\
\text { experience as ICU nurses } \\
\text { There is positive correlation } \\
\text { between attitude toward } \\
\text { WLST and role perception. }\end{array}$ \\
\hline $\begin{array}{l}\text { Je \& Hwa } \\
(2018)[14]\end{array}$ & $\begin{array}{l}\text { Cross-sectional } \\
\text { study }\end{array}$ & $\begin{array}{l}\text { A tertiary } \\
\text { general } \\
\text { hospital }\end{array}$ & $\begin{array}{l}\text { Self-reported } \\
\text { questionnaire } \\
\text { developed by } \\
\text { Byun (2003) }\end{array}$ & $\begin{array}{l}95 \text { nurses } \\
16 \text { professors } \\
76 \text { doctors } \\
14 \text { medical } \\
\text { technician } \\
7 \text { Assisted } \\
\text { nurses } \\
20 \\
\text { administrative } \\
\text { staff }\end{array}$ & $\begin{array}{l}\text { The mean score of } \\
\text { nurses' was } 3.36 \\
\text { The mean score of profes- } \\
\text { sors' was } 3.23 \\
\text { The mean score of doc- } \\
\text { tors' was } 3.23 \\
\text { The mean score of medi- } \\
\text { cal technicians' was } 3.31 \\
\text { The mean score of assist } \\
\text { nurses' was } 2.86 \\
\text { The mean score of admin- } \\
\text { istrative staff's was } 3.21\end{array}$ & $\begin{array}{l}\text { Attitude toward WLST was } \\
\text { Significantly different by job } \\
\text { and working unit } \\
\text { There was positive } \\
\text { correlation between attitude } \\
\text { toward WLST and attitude } \\
\text { about tissue donation and } \\
\text { tissue transplantation. } \\
\text { There was positive } \\
\text { correlation between attitude } \\
\text { toward WLST and awareness } \\
\text { of death. } \\
\text { There was positive } \\
\text { correlation between attitude } \\
\text { toward WLST and awareness } \\
\text { of hospice palliative care. } \\
\text { Attitude toward WLST } \\
\text { was affected by working } \\
\text { at hospice ward, attitude } \\
\text { about tissue donation and } \\
\text { tissue transplantation, } \\
\text { and awareness of hospice } \\
\text { palliative care. Attitude } \\
\text { toward WLST was explained } \\
\text { by } 32.5 \% \text { by variances. }\end{array}$ \\
\hline
\end{tabular}




\begin{tabular}{|l|l|l|l|l|l|l|}
\hline $\begin{array}{l}\text { Um, Suh, \& } \\
\text { Park (2018) } \\
{[13]}\end{array}$ & $\begin{array}{l}\text { Cross-sectional } \\
\text { study }\end{array}$ & $\begin{array}{l}\text { ICU from } \\
\text { 2 general } \\
\text { hospitals }\end{array}$ & $\begin{array}{l}\text { Self-reported } \\
\text { questionnaire } \\
\text { developed by } \\
\text { Byun (2003) }\end{array}$ & 127 ICU nurses & The mean score was 3.23 & $\begin{array}{l}\text { Attitude toward WLST was } \\
\text { Significantly different by } \\
\text { gender } \\
\text { There was no correlation } \\
\text { between attitude toward } \\
\text { WLST and stress and } \\
\text { advanced directives } \\
\text { awareness in ICU nurses. }\end{array}$ \\
\hline
\end{tabular}

